\title{
Performance of Some Grape Cultivars for Commercial Cultivation in West Bengal
}

\author{
Ranjit Pal ${ }^{1 *}$, P. Deb ${ }^{2}$ and S. N. Ghosh ${ }^{1}$ \\ ${ }^{1}$ Dept. of Fruits and Orchard Management, Faculty of Horticulture, Bidhan Chandra Krishi Viswavidyalaya, Mohanpur, Nadia, \\ West Bengal (741 252), India \\ ${ }^{2}$ Dept. of Crop Improvement, Horticulture and Agricultural Botany, Palli Siksha Bhavana (Institute of Agriculture), Visva-Bharari, \\ Sriniketan, Birbhum, West Bengal (731 236), India
}

\author{
Corresponding Author \\ Ranjit Pal \\ e-mail: ranjit_pal2@yahoo.com
}

\author{
Article History \\ Article ID: AR1874a \\ Received in $26^{\text {th }}$ April, 2018 \\ Received in revised form $23^{\text {rd }}$ September, 2018 \\ Accepted in final form $24^{\text {th }}$ September, 2018
}

\begin{abstract}
The experiment was carried out for two consecutive years during 2010 and 2012 at the experimental grape orchard at Horticultural Research and Development Farm, Govt. of W.B, Taldangra, Bankura. The experiment was conducted in randomized block design with four replications. The vines were trained on ' $Y$ '-trellies system and spacing of $2 \times 3 \mathrm{~m}^{2}$. The vine was pruned on $30^{\text {th }}$ January. As per fruit maturity, the cultivars Pusa Navrang were considered to be the earliest harvesting. Among the twelve cultivars, maximum fruit yield was recorded in Arka Neelamani (7.81 kg vine-1). The number of bunches/vine were varied significantly among the cultivars with number of bunches/ vine highest in cultivar Arka Trishna. But bunch weight was highest in cultivar Arkavati (264.2 g). Size of the bunch was maximum in Arka Kanchan. However, different cultivars of grape exhibited significant variation with respect to average ten berries weight. The ten berries weight was highest in Arka Magestic. The cultivars Arka Trishna gave the highest juice \%, total soluble solids, lowest acidity, highest TSS/acid ratio and sugar content. Ascorbic acid content highest was recorded from cultivar Pusa Navrang as compared to other cultivars. Incidence of major insects and diseases determine the economic feasibility of a cultivar in the area. It appears from the good performed cultivars less incidence of major insects and diseases during flowering to fruiting period. On the basis of marketable yield, fruit quality and tolerance to pest, cultivars Arka Neelamani for table purpose can be recommended for commercial cultivation under Bankura conditions of West Bengal.
\end{abstract}

Keywords: Grape, cultivars, laterite soil, performance

\section{Introduction}

Viticulture in India assumes an important position in horticulture crop in view of its area, production, value addition and job creation in both rural and urban areas. Among all the horticultural crops, grapes have received a special importance in view of its value addition into raisins and wines. Traditionally, grapes are one of the most important fruit crops of temperate zone of the world, but presently its cultivation is becoming also popular in the tropical and subtropical regions of the world. There has been a steady increase in the area and production of grape in the country as a result of identification and development of suitable cultivars and standardization of their agro-techniques.

In western part of West Bengal, which covers 5 districts viz., Bankura, Birbhum, Paschim Midnapur, Purulia and some part of Burdwan where the soil is red and laterite is highly suitable for cultivation of grapes on commercial scale as the area receives low rainfall during January to May and experiences a long dry spell during summer. It is well known that bright sunlight and rainless days essential during flowering and fruiting of grapes (Ghosh et al., 2008). Early ripening varieties and those that are less sensitive to rain have better possibility for commercial cultivation under western part of West Bengal conditions. Therefore, main objective of the present investigation was undertaken to evaluate different cultivars of grape for commercial cultivation in western parts of West Bengal. Hence, an attempt has been made in this aspect.

\section{Materials and Methods}

The experiment was carried out at experimental grape orchard at Horticultural Research and Development Farm, of by Govt. of West Bengal, at Taldangra in the district of Bankura, West Bengal, India. Geographically the farm is situated at $23^{\circ} 01^{\prime} 60^{\prime \prime}$ $\mathrm{N}$ latitude and $87^{\circ} 06^{\prime} 00^{\prime \prime} \mathrm{E}$ longitude at an elevation of 88.0 meters above main sea level. The site is sub-tropical climate with little summer rainfall. The average precipitation (June to October) in this area about $1100 \mathrm{~mm}$. The maximum 
and minimum temperature during summer months varies between $40^{\circ} \mathrm{C}$ and $24{ }^{\circ} \mathrm{C}$ respectively while during winter it ranges between $25.5^{\circ} \mathrm{C}$ and $11.2{ }^{\circ} \mathrm{C}$. The soil of the orchard was laterite having pH 6.0, Organic Carbon $0.55 \%$. Available (natural) soil content of nitrogen $(\mathrm{N})$, phosphorus $\left(\mathrm{P}_{2} \mathrm{O}_{5}\right)$ and potassium $\left(\mathrm{K}_{2} \mathrm{O}\right)$ was $294.30,40.62$ and $121.11 \mathrm{~kg} \mathrm{ha}^{-1}$ respectively. Rooted cuttings of twelve cultivars collected from different parts of India, were planted in the collection block at $2 \times 3 \mathrm{~m}^{2}$ distance, during January, 2008 and vines were trained on ' $\gamma$ ' trellis system.

The experimental material consisted of twelve cultivars, viz., Arka Neelamani, Pusa Navrang, Arkavati, Black Prince, Arka Shyam, Madhu Angur, Arka Kanchan, Arka Trishna, Carolina Black Rose, Arka Soma, Arka Chitra, Arka Magestic. The experiment was carried out for two consecutive years during 2010 and 2012. The experiment was conducted in randomized block design with four replications. The observations were vine yield and physical characteristics of fruits were recorded when the fruits were ready for harvest. For chemical analysis of the fruits, the methods were followed as described by A.O.A.C. (1990).

The pruning operation was done during last week of January. Immediately after pruning, followed by pasting of Dorbreak (Hydrogen cyanamide at $1.5 \%$ ), a bud breaking chemical. All other cultural practices like manuring and fertilization, Irrigation, application of growth regulators, weeding, plant protection, etc. were carried out uniformly to all the vines. The data were analyzed statistically and test of significant were done by following the method RBD as described by Pance and Sukhatme (1985).

\section{Results and Discussion}

\subsection{Pruning to harvesting period}

The data presented Table 1 reveals that cultivar Arka Chitra took minimum of 15.12 days for flower bud development after pruning while in Madhu Angur it was 24.37 days. The cultivar Arka Neelamani took maximum of 31.50 days required for floral bud initiation to fruit set while Arka Chitra took minimum of 17.37 days. Arka Trishna required 78.87 days for fruit set to maturity and Pusa Navrang required only 51.37 days for maturity from fruit set. Among the 12 cultivars, Pusa Navrang was early cultivar and Arka Trishna and Arka Kanchan was late cultivar. The studies are in confirmation with the earlier works made by Ghosh et al. (2012).

\subsection{Physiological behaviour of pruned fruiting spur}

It appears from the Table 2 noted that among the 12 cultivars, the physiological behaviour of pruned fruiting spur in term of fruitfulness of spur was found highest in Arka Trishna (98.37\%) followed by Arka Neelamani (89.94\%) and Arka Shyam (72.09\%). The fruitfulness of spur in different cultivars of grapes mainly depends on different agro-climacteric condition and horticultural practices that are followed. No much literature is available regarding fruitfulness behaviour
Table 1: Time taken for floral bud initiation, fruit set, fruit maturity and date of harvesting of grape grown in Bankura district

\begin{tabular}{lcccc}
\hline Cultivars & 1 & 2 & 3 & 4 \\
\hline Arka Neelamani & 18.87 & 31.50 & 57.75 & $20^{\text {th }}$ May \\
Pusa Navrang & 18.87 & 23.12 & 51.37 & $05^{\text {th }}$ May \\
Arkavati & 21.00 & 23.87 & 64.00 & $20^{\text {th }}$ May \\
Black Prince & 21.00 & 22.37 & 74.75 & $30^{\text {th }}$ May \\
Arka Shyam & 21.12 & 24.50 & 71.87 & $29^{\text {th }}$ May \\
Madhu Angur & 24.37 & 19.75 & 68.50 & $24^{\text {th }}$ May \\
Arka Kanchan & 18.50 & 31.25 & 71.00 & $01^{\text {st }}$ June \\
Arka Trishna & 19.87 & 18.87 & 78.87 & $30^{\text {th }}$ May \\
Carolina Black Rose & 24.25 & 22.25 & 65.37 & $23^{\text {rd }}$ May \\
Arka Soma & 18.25 & 24.37 & 64.62 & $19^{\text {th }}$ May \\
Arka Chitra & 15.12 & 17.37 & 69.37 & $14^{\text {th }}$ May \\
Arka Magestic & 24.25 & 18.50 & 60.00 & $14^{\text {th }}$ May \\
CD ( $p=0.05)$ & 0.66 & 0.70 & 1.40 & - \\
\hline
\end{tabular}

1: Time taken for floral bud initiation after pruning (Days after pruning); 2: Time taken from floral bud initiation to fruit set (Days); 3: Time taken from fruit set to maturity (days); 4: Date of Harvesting

of various cultivars in different climatic zones of India.

\subsection{Vine yield and physical characteristics of Berry}

The data clear from Table 2 showed that yield and physical characteristics of fruits of different cultivars varied significantly. Highest yield vine ${ }^{-1}$ was recorded from cultivar Arka Neelamani $(7.81 \mathrm{~kg})$ followed by Arka Shyam $(2.64 \mathrm{~kg}$ ) and Arka Trishna $(2.63 \mathrm{~kg})$. Highest number of bunch/vine was counted from Arka Trishna (29.62), followed by Arka Shyam (28.37) and Arka Neelamani (27.50). These three cultivars did not significantly differ with each others. The increase in number of bunches/ vine in Arka Trishna may be due to highest fruitfulness of spur. Similar results have also been reported by Ghosh et al., (2012) under Jhargram condition. The varietal suitability in different regions of India has been reported by Chadha and Sikhamany (1999). Various grape varieties have been found to perform well in various regions owing to different climatic and other environmental conditions. Many varieties which are doing extremely well in one region may have not doing so well in other regions. Chadha (2008) reported that the cultivar Perlette is grown as commercially in northern part of India. While Thompson Seedless and Sharad Seedless among the seedless cultivars, and Anab-e-Shahi, Gulabi and Bangalore Blue among the seeded cultivars are cultivated in Maharashtra and southern states. Kumar and Rajan (2008) reported that Flame seedless and Pusa Navrang could be commercially grown in North Indian condition. Kumar et al. (2002) reported that under north India condition respond Beauty seedless and Flame seedless most suitable cultivars for commercial 


\begin{tabular}{|c|c|c|c|c|c|c|c|}
\hline Cultivars & $\begin{array}{l}\text { Fruitfulness } \\
\text { of spur (\%) }\end{array}$ & $\begin{array}{l}\text { Yield vine }^{-1} \\
(\mathrm{~kg})\end{array}$ & $\begin{array}{l}\text { No. of bunches } \\
\text { vine }^{-1}\end{array}$ & $\begin{array}{c}\text { Bunch } \\
\text { weight }(\mathrm{g})\end{array}$ & $\begin{array}{l}\text { Length of } \\
\text { bunch }(\mathrm{cm})\end{array}$ & $\begin{array}{l}\text { Breadth of } \\
\text { bunch }(\mathrm{cm})\end{array}$ & $\begin{array}{l}10 \text { Berries } \\
\text { weight }(\mathrm{g})\end{array}$ \\
\hline Arka Neelamani & 89.94 & 7.81 & 27.50 & 236.0 & 15.4 & 10.7 & 29.46 \\
\hline Pusa Navrang & 66.40 & 1.57 & 10.12 & 147.6 & 13.0 & 8.8 & 12.39 \\
\hline Arkavati & 45.10 & 1.83 & 6.75 & 264.2 & 15.3 & 10.2 & 27.06 \\
\hline Black Prince & 17.49 & 0.39 & 1.75 & 209.5 & 11.8 & 6.1 & 24.16 \\
\hline Arka Shyam & 72.09 & 2.64 & 28.37 & 85.3 & 12.9 & 5.4 & 17.44 \\
\hline Madhu Angur & 8.04 & 0.14 & 1.12 & 132.8 & 12.5 & 9.9 & 29.00 \\
\hline Arka Kanchan & 38.20 & 0.92 & 3.75 & 249.0 & 14.4 & 11.9 & 24.95 \\
\hline Arka Trishna & 98.37 & 2.63 & 29.62 & 90.9 & 11.5 & 7.3 & 30.52 \\
\hline Carolina Black Rose & 19.02 & 0.54 & 3.12 & 177.2 & 13.0 & 9.6 & 28.99 \\
\hline Arka Soma & 10.27 & 0.22 & 1.62 & 132.9 & 11.6 & 9.4 & 24.17 \\
\hline Arka Chitra & 12.02 & 0.18 & 1.37 & 135.2 & 11.6 & 8.8 & 24.20 \\
\hline Arka Magestic & 18.00 & 0.36 & 2.00 & 185.8 & 11.8 & 10.8 & 35.73 \\
\hline$C D(p=0.05)$ & 1.52 & 0.35 & 2.37 & 13.63 & 1.85 & 0.54 & 1.16 \\
\hline
\end{tabular}

cultivation. Karibasappa and Adsule (2008) reported that the cultivar Pusa Navrang gave the highest $\left(19 \mathrm{t} \mathrm{ha}^{-1}\right)$ yield vine ${ }^{-1}$ under Pune condition of Maharashtra.

The bunch weight was highest from Arkavati (264.20 g), followed by Arka Kanchan ( $249.00 \mathrm{~g}$ ) and Arka Neelamani $(236.00 \mathrm{~g})$. Size (length $\times$ breadth) of the bunch was recorded highest in Arka Kanchan $\left(14.4 \times 11.9 \mathrm{~cm}^{2}\right)$ followed by Arka Neelamani $\left(15.4 \times 10.7 \mathrm{~cm}^{2}\right)$ and Arkavati $\left(15.3 \times 10.2 \mathrm{~cm}^{2}\right)$. The maximum ten berries weight was recorded from Arka Magestis (35.73 g), followed by Arka Trishna (30.52 g) and Arka Neelamani (29.46 g). The studies are in confirmation with the results of Ghosh et al. (2012) under Jhargram condition.

\subsection{Chemical characteristics of Berry}

The chemical composition of fruits of different grape cultivars has been presented in Table 3. Highest juice content (77.84\%), total soluble solids (20.8 $\mathrm{brix})$, TSS/acid ratio (48.37) highest total sugar (14.90\%) and reducing sugar (12.69\%) were recorded from cultivar Arka Trishna followed by Arka Neelamani. The acid content was lowest in Arka Trishna (0.43\%) followed by Arka Neelamani $(0.49 \%)$ and highest was recorded from Arka Magestic (0.87\%). The ascorbic acid content was highest in Pusa Navrang $(8.00$ mg/100 ml

\begin{tabular}{lccccccccc}
\hline \multicolumn{7}{l}{ Table 3: Fruit quality characteristics of different cultivars of grape grown in Bankura district } \\
\hline Cultivars & $\begin{array}{c}\text { Juice } \\
\text { (\%) }\end{array}$ & $\begin{array}{c}\text { TSS } \\
\text { ('Brix) }\end{array}$ & $\begin{array}{c}\text { Acidity } \\
\text { (\%) }\end{array}$ & $\begin{array}{c}\text { TSS/acid } \\
\text { ratio }\end{array}$ & $\begin{array}{c}\text { Total } \\
\text { sugar (\%) }\end{array}$ & $\begin{array}{c}\text { Reducing } \\
\text { sugar (\%) }\end{array}$ & $\begin{array}{c}\text { Ascorbic acid } \\
\text { (mg/100 ml } \\
\text { juice) }\end{array}$ & Berry colour & $\begin{array}{c}\text { J u ice } \\
\text { colour }\end{array}$ \\
\hline Arka Neelamani & 73.49 & 20.5 & 0.49 & 41.83 & 13.87 & 12.56 & 3.94 & Reddish black & Ivory \\
Pusa Navrang & 70.83 & 15.0 & 0.80 & 18.78 & 11.74 & 10.79 & 8.00 & Black & Red \\
Arkavati & 67.21 & 17.8 & 0.55 & 33.25 & 12.46 & 11.16 & 4.35 & Greenish yellow & Ivory \\
Black Prince & 67.32 & 19.0 & 0.60 & 31.74 & 14.80 & 12.24 & 3.71 & Reddish black & Ivory \\
Arka Shyam & 68.67 & 16.1 & 0.74 & 22.34 & 12.76 & 11.99 & 3.94 & Black & Ivory \\
Madhu Angur & 70.86 & 18.4 & 0.56 & 32.66 & 14.06 & 12.21 & 3.47 & Reddish black & Ivory \\
Arka Kanchan & 68.70 & 16.3 & 0.58 & 27.75 & 12.20 & 11.00 & 3.60 & Greenish yellow & Ivory \\
Arka Trishna & 77.84 & 20.8 & 0.43 & 48.37 & 14.90 & 12.69 & 5.24 & Rusty-brown & Ivory \\
Carolina Black Rose & 74.45 & 18.1 & 0.60 & 30.20 & 13.93 & 12.01 & 3.83 & Reddish black & Ivory \\
Arka Soma & 67.30 & 17.4 & 0.69 & 25.03 & 13.67 & 12.14 & 3.64 & Greenish yellow & Ivory \\
Arka Chitra & 69.45 & 16.8 & 0.69 & 24.45 & 13.55 & 11.83 & 3.48 & Greenish yellow & Ivory \\
Arka Magestic & 67.49 & 14.7 & 0.87 & 16.93 & 10.97 & 10.18 & 3.27 & Reddish Black & Ivory \\
CD ( $p=0.05)$ & 1.74 & 0.56 & 0.05 & 2.13 & 0.66 & 0.88 & 1.32 & -- & -- \\
\hline
\end{tabular}


of juice) and lowest in Arka Magestic $(3.27 \mathrm{mg} / 100 \mathrm{ml}$ of juice). Results of the present observation are in line with the findings of Ghosh et al. (2005) under Jhargram condition. It was interesting to note fruit quality of different cultivars of grape under Bankura condition was better as compared to same cultivars under Bhatinda condition of Punjab (Thakur et al., 2008) under Bhatinda condition maximum TSS of $18.23 \%$ and lowest acidity $0.68 \%$ was recorded in Deligate while under Bankura condition highest TSS of $19.8^{\circ}$ brix with $0.43 \%$ acidity was recorded from Arka Trishna. Singh et al. (1998) also stated that the fruit quality of Arka Neelamani was superior because of high sugar content and crispy pulp of berries.

\subsection{Colour of berry and Juice}

The data presented in Table 3 revealed that colour of berry was reddish black in Arka Neelamani, Black Prince, Madhu
Angur, Carolina Black Rose and Arka Magestic; black in Pusa Navrang and Arka Shyam; greenish yellow in Arkavati, Arka Kanchan, Arka Soma and Arka Chitra; and rusty brown in Arka Trishna. Juice colour was ivory in Arka Neelamani, Arkavati, Black Prince, Arka Shyam, Madhu Angur, Arka Kanchan, Arka Trishna, Carolina Black Rose, Arka Soma, Arka Chitra and Arka Magestic; red in Pusa Navrang.

\subsection{Incidence of pests}

Incidence of major insects and diseases determine the economic feasibility of a cultivar in an area. It appears from the Table 4 that most of the good performed cultivars showed less incidence of major insects (thrips, mealy bug and flea bettle) and diseases (anthracnose and downy mildew) during flowering and fruiting period.

\begin{tabular}{lcr}
\hline \multicolumn{3}{l}{ Table 4: Incidence of insects and diseases of different cultivars } \\
\hline Cultivars & Thrips & Mealy bug \\
\hline Arka Neelamani & Resistance & Tolerance \\
Pusa Navrang & Resistance & Tolerance \\
Arkavati & Susceptible & Tolerance \\
Arka Shyam & Tolerance & Tolerance \\
Madhu Angur & Susceptible & Tolerance \\
Arka Kanchan & Tolerance & Tolerance \\
Arka Trishna & Resistance & Tolerance \\
Carolina Black Rose & Susceptible & Tolerance \\
Arka Soma & Resistance & Tolerance \\
Arka Chitra & Resistance & Tolerance \\
Arka Magestic & Susceptible & Tolerance \\
\hline 3. Conclusion & & \\
The cultivar Arka Neelamani can be recommended for \\
commercial cultivation in Bankura district of West Bengal and \\
as it gave highest yield attributing characters and second best \\
in quality of fruit. The cultivars Arka Shyam and Arka Trishna \\
can also be consider for good yield and quality.
\end{tabular}

\section{Acknowledgement}

The authors highly thankful to Food Processing Industry and Horticulture, Govt. of West Bengal for providing financial assistance for the study.

\section{Reference}

AOAC, 1990. Official method of analysis. Association of official analytical chemists ( $15^{\text {th }}$ edn.). Washington, D.C.

Chadha, K.L., 2008. Indian viticulture scenario. Acta Horticulturae (785), 59-68.

Chadha, K.L., Shikhamany, S.D., 1999. The Grapes. Improvement, Production and Post-harvest Management, Malhotra
Publishing House, New Delhi, 578.

Ghosh, S.N., Tarai, Ranjan, Ray, S.K.D., 2005. Initial evaluation of some grape cultivars in laterite soils of West Bengal. Orissa Journal of Horticulture 33(2), 109-113.

Ghosh, S.N., Tarai, R., Pal, P.P., 2008. Performance of eight grape cultivars in Laterite soil of West Bengal. Acta Horticulturae 785, 73-77.

Ghosh, S.N., Bera, B., Roy, S., Kundu, A., 2012. Adaptation and commercialization of viticulture in West Bengal - a new area in India. Acta Horticulturae (931), 389-399.

Karibasappa, G.S., Adsule, P.G., 2008. Evaluation of wine grape genotypes by national research centre for grapes at their farm at Pune, Maharashtra, India. Acta Horticulturae 785(785), 497-504.

Kumar, R., Rajan, S., Negi, S.S., 2002. Evaluation of earlyripening grape genotypes under subtropical North Indian conditions. Journal of Applied Horticulture, Lucknow $4(1), 60-62$.

Kumar, R., Rajan, S., 2008. Grape cultivars flame seedless and Pusa Navrang can be commercially grown in north Indian 
conditions. Acta Horticulturae 785, 69-72.

Panse, V.G., Sukhatme, P.V., 1985. Design of Experiments. VIII Randomized Blocks and Latin Square. In: Statistical methodology for Agricultural workers, Indian Council of Agricultural Research, New Delhi, 110001, 1, 145-156. Singh, R., Murthy, B.N.S., Rama, S.T., 1998. 'Arka Neelamani',
'Arka Shweta', 'Arka Majestic' and 'Arka Chitra': new hybrid grapes. Indian Horticulture 43, 28-29.

Thakur, A., Arora, N.K., Singh, S.P., 2008. Evaluation of some grape varieties in the arid irrigated region of northwest India. Acta Horticulturae 785, 79-83. 